\title{
Ellipsis
}

2015

\section{Sprawl City Coroner}

\author{
Christian Coleman \\ University of New Orleans
}

Follow this and additional works at: https://scholarworks.uno.edu/ellipsis

\section{Recommended Citation}

Coleman, Christian (2015) "Sprawl City Coroner," Ellipsis: Vol. 42 , Article 6.

DOI: https://doi.org/10.46428/ejail.42.06

Available at: https://scholarworks.uno.edu/ellipsis/vol42/iss1/6

This Poetry is brought to you for free and open access by the Department of English and Foreign Languages at ScholarWorks@UNO. It has been accepted for inclusion in Ellipsis by an authorized editor of ScholarWorks@UNO.

For more information, please contact scholarworks@uno.edu. 


\title{
Sprawl City Coroner
}

Christian Coleman

\author{
Andrea Saunders Gereighty / Academy of American Poets Award $3^{\text {rd }}$ Place
}

On the mangled cherry trees bending in his front yard, bloated and swollen, the maggots eat

like kings. The bodies swing from low branches

to be plucked by the Doctor. He paints their shadows

on the ground with black tar so the bodies know

where they have been. He keeps sticks

sharpened on both ends.

What they were the city has taken

as burnt offerings. The corpses of the unclaimed, stacked

like firewood on pyres. The Doctor makes

smoke signals of the dead. Gods

come when he calls 